\title{
Manufactures Non-Generics
}

National Cancer Institute

\section{Source}

National Cancer Institute. Manufactures Non-Generics. NCI Thesaurus. Code C101886.

A business that makes brand name products. 